\title{
Merkezi Yolla Enjekte Edilen Histamin ve Reseptör Antagonistlerinin, Sıçanların Yem, Su Alımı ve Vücut Ağırlıkları Üzerine Etkileri
}

\author{
Burçin ALTINBAŞ ${ }^{1}$ (๑) , Gökçen GÜVENÇ BAYRAM ${ }^{2}$ ๑), Murat YALÇIN ${ }^{3}$ ๑ \\ ${ }^{1}$ SANKO Üniversitesi Tip Fakültesi, Fizyoloji Anabilim Dalı, Gaziantep, Türkiye \\ ${ }^{2}$ Dokuz Eylül Üniversitesi Veteriner Fakültesi, Fizyoloji Anabilim Dal, İzmir, Türkiye \\ ${ }^{3}$ Bursa Uludağ Üniversitesi Veteriner Fakültesi, Fizyoloji Anabilim Dalı, Bursa, Türkiye
}

Bu makaleye yapılacak atıf: Altınbaș B ve ark. Merkezi Yolla Enjekte Edilen Histamin ve Reseptör Antagonistlerinin, Sıçanların Yem, Su Alımı ve Vücut Ağırlıkları Üzerine Etkileri. Turk J Diab Obes 2021;2: 210-216.

\begin{abstract}
ÖZ
Amaç: Başta hipotalamus olmak üzere merkezi sinir sisteminde geniş bir dağılım gösteren histamin birçok otonomik işlevin düzenlenmesinde bir nörotransmitter veya nöromodülatör olarak rol almaktadır. Hipotalamusta; yiyecek, su alımı ve vücut ağırlığının düzenlenmesinde görev alan birçok çekirdekte histamin reseptörleri geniş bir dağılıma sahiptir. Çalışmada, merkezi yolla histamin, klorfeniramin, ranitidin ve tiyoperamid tedavilerinin sıçanlarda oluşturduğu yiyecek ve su alımı ile vücut ağırlığı değişimleri araştırılmiştır.

Gereç ve Yöntemler: Çalışma, Sprague-Dawley ırkı sıçanlarda gerçekleştirilmiştir. Histamin (100 nmol), histaminerjik H1 reseptör antagonisti klorfeniramin (100 nmol), histaminerjik H2 reseptör antagonisti ranitidin (100 nmol) veya histaminerjik H3/H4 reseptör antagonisti tiyoperamid (100 nmol) serebral yan ventriküler yolla günde bir kez olacak şekilde 7 gün boyunca enjekte edilmiştir. Veriler IBM SPSS Statistics (v23) paket programı ile analiz edilmiştir. Verilerin analizinde, Kolmogorov-Smirnov Testi, ANOVA ve Dunnet testleri kullanılmıştır. $\mathrm{p}<0,05$ istatistiksel olarak anlamlı sayılmıştır.

Bulgular: Histamin, klorfeniramin ve ranitidinin gıda ve su alımı ile vücut ağırlığında azalmalara neden olmuştur (p<0,05). Fakat tiyoperamid ile yapılan tedavi bahsedilen ilaçların tersine gıda ve su alımı ile vücut ağırlığında artışlara yol açmıştır $(\mathrm{p}<0,05)$.

Sonuç: Elde edilen veriler, 7 günlük tedaviler sonrasında merkezi histamin, klorfeniramin ve ranitidin tedavilerinin beslenmenin düzenlenmesinde negatif etkilere yol açtığını göstermektedir. Bunun yanında, merkezi tiyoperamid ile yapılan 7 günlük tedavinin gıda ve su alımı ile kilo alımına neden olduğu ortaya çıkmıştır.
\end{abstract}

Anahtar Sözcükler: Histamin, Histamin antagonistleri, Gıda alımı, Su alımı, Vücut ă̆ırlı̆̆

\section{Effects of Centrally Injected Histamine and Receptor Antagonists on Feed, Water Intake and Body Weight of Rats}

\begin{abstract}
Aim: The histaminergic system, which has a wide distribution in the central nervous system, especially the hypothalamus, plays a role as a neurotransmitter or neuromodulator in the regulation of many autonomic functions. In the hypothalamus, histamine receptors are widely distributed in many nuclei involved in the regulation of food, water intake and body weight. In this study, food and water intake and body weight changes caused by histamine, chlorpheniramine, ranitidine and thioperamide treatments chronically in rats were investigated.

Material and Methods: The study was carried out in Sprague-Dawley rats. Histamine (100 nmol), histaminergic H1 receptor antagonist chlorpheniramine (100 nmol), histaminergic $\mathrm{H} 2$ receptor antagonist ranitidine (100 nmol), or histaminergic $\mathrm{H} 3 / \mathrm{H} 4$ receptor antagonist thioperamide $(100 \mathrm{nmol})$ were injected via the cerebral side ventricular route for 7 days. The data were analyzed with the IBM SPSS

ORCID: Burçin Altınbaş / 0000-0002-9534-736X, Gökçen Güvenç Bayram / 0000-0002-1413-3651, Murat Yalçı / 0000-0002-5600-8162


Statistics (v23) package program. In the analysis of the data, Kolmogorov-Smirnov Test, ANOVA and Dunnet tests were used. $\mathrm{p}<0.05$ was considered statistically significant.

Results: Histamine, chlorpheniramine and ranitidine caused reductions in food and water intake and body weight ( $p<0,05)$. However, treatment with thioperamide led to increases in food and water intake and body weight, unlike the aforementioned drugs $(\mathrm{p}<0,05)$.

Conclusion: As a result, the data obtained show that after 7 days of treatments, central histamine, chlorpheniramine and ranitidine treatments cause negative effects on the regulation of nutrition. In addition, it was revealed that 7 days of treatment with central thioperamide caused weight gain with food and water intake.

Keywords: Histamine, Histamine antagonists, Eating, Drinking, Body weight

\section{GİRIș}

Histamin, merkezi sinir sistemi (MSS) içerisinde arka hipotalamusun tüberomamiller çekirdeğinden kaynaklanan sınırlı bir nöron popülasyonuna sahiptir. Bu bölgeden köken alan histaminerjik nöronlar, çeşitli beyin bölgelerine dağınık bir şekilde projeksiyon yaparlar ve bu yaygın projeksiyonla paralel olarak, histamin reseptörlerinin 4 alt tipi $\left(\mathrm{H}_{1}, \mathrm{H}_{2}, \mathrm{H}_{3}\right.$ ve $\left.\mathrm{H}_{4}\right)$, MSS'nin hemen hemen tüm bölümlerine dağılmıştır (1-3). MSS içerisinde bir nörotransmitter ve nöromodülatör özelliğe sahip histamin, enerji dengesi, ağrı, öğrenme ve hafıza, termoregülasyon, solunum sistemi ve kardiovasküler sistemin kontrolü gibi çok sayıda fizyolojik olayın gerçekleşmesine aracılık etmektedir $(2,4)$. Bunların yanında çalışmalar, merkezi histaminin vücut ağırlığı, gıda ve su alımının düzenlenmesinde rol oynayabileceğini de göstermektedir $(5,6)$. Histaminin merkezi enjeksiyonlarının, sıçanlarda (7), kedilerde (8) ve keçilerde (9) gıda alımını baskıladığ 1 ortaya konmaktadır. Yine, histamin katabolizmasını engelleyen metoprin ile yapılan çalışmalarda da gida alımının baskılandığı gözlenmiştir (10) Histaminin MSS'de gıda alımı üzerinde oluşturduğu inhibe edici etkilere merkezi histamin $\mathrm{H}_{1}$ reseptörlerinin aracılık ettiği rapor edilmektedir $(11,12)$. Histaminin, anterior, lateral, preoptik veya anterior-lateral hipotalamusa mikro-enjeksiyonlarının su alımını artırdığı gösterilmiştir (13). Histaminin su alımı üzerindeki etkilerini ise $\mathrm{H}_{3}$ reseptörleri üzerinden gerçekleştirdiği belirtilmektedir (14). Histaminin vücut ağırlığ 1 üzerine etkilerini inceleyen çalışmalar, merkezi histamin uygulamasının serum serbest yağ asidi seviyelerinde artışa neden olduğunu ve buna paralel olarak vücut ağırlığında azalmaların meydana geldiğini göstermektedir $(15,16)$. Bununla tutarlı olarak, histamin, histamin $\mathrm{H}_{1}$ reseptörü ve histamin $\mathrm{H}_{3}$ reseptörü nakavt farelerde obezite geliștiği de rapor edilmektedir (17-19).

Sonuç olarak, araştırmalar merkezi histaminerjik sistemin vücut ağırlığının, yem ve su alımının düzenlenmesinde anahtar bir role sahip olduğunu göstermektedir. Bu bilgiler doğrultusunda bu çalışmada 7 gün süre ile histamin ve histamin reseptör antagonist tedavilerinin sıçanlarda vücut ağırlığı, gıda ve su alımı üzerindeki rollerini ortaya koymak amaçlanmıștır.

\section{GEREÇ ve YÖNTEMLER}

\section{Genel}

Çalışmada, 2-4 aylık Sprague Dawley türü (250-300 g) erişkin 35 adet erkek sıçan kullanıldı. Sıçanların, deney öncesinde 4'lü gruplar hâlinde, su ve yem alımları serbest bırakılarak bakımları sağlandı. Sıçanların bulunduğu ortamın 1sısı $20-24{ }^{\circ} \mathrm{C}$ olacak şekilde sabit tutularak oda 12 saat aydınlık ve 12 saat karanlık (07.00-19.00 arası aydınlık) döngüsüyle aydınlatıldı. Hayvanlar deney hayvanı yetiştirme merkezinden alındıktan sonra, yukarıda belirtilen koşulların sağlandığı deney hayvanı bakım odasında en az iki hafta süre ile dinlendirildi. Çalışmadaki tüm cerrahi ve deneysel uygulamalar, Bursa Uludağ Üniversitesi Etik Kurul Komitesi tarafindan 2021-04/01 Karar No ile onayland.

\section{Genel Hazırlık ve Cerrahi İșlemler}

Siçanlar, sevofluran (\%2-4/\%100 $\left.\mathrm{O}_{2}\right)$ ile anestezi edildi. Anestezi altında, sıçanların kafatasları stereotaksik alete yerleştirilerek sabitlendi ve kafa derisi orta hattan kesilip kemik net bir şekilde ortaya çıkarıldı. Serebral yan ventrikül (s.y.v.) yolla ilaçların verilmesi için Paxinos ve Watson'un Sıçan Beyin Atlası'nda (20) belirtilen koordinatlara göre bregmanın 1,0 $\mathrm{mm}$ posterioru, orta hattın $1,5 \mathrm{~mm}$ lateralinde kafatasına bir delik açılarak, 22 G'lık paslanmaz çelik iğneden hazırlanmış kafatasından itibaren $4,5 \mathrm{~mm}$ vertikale ulaşacak olan kılavuz kanül bu delikten sokularak lateral ventriküle doğru itildi. Bu şekilde, s.y.v. için yerleştirilen kılavuz kanül dişçi akriliği ile kafatasına tutturuldu.

\section{Deneysel Protokol}

Çalışmada, histamin ve histamin reseptörleri antagonistlerinin 7 gün boyunca uygulanan merkezi tedavilerinin vücut ağırlığı, gıda ve su alımına etkisini göstermek için hayvanlar 5 gruba ayrıldı. Her gruba ayrı bir ilaç enjeksiyonu uyguland. Bu doğrultuda hayvanların s.y.v.'lerine \% 0,9'luk tuzlu su $(5 \mu \mathrm{L} ; \mathrm{n}=7)$, histamin ( $100 \mathrm{nmol} ; \mathrm{n}=7)$, histaminerjik $\mathrm{H}_{1}$ reseptör antagonisti klorfeniramin (100 nmol; $\mathrm{n}=7)$, histaminerjik $\mathrm{H}_{2}$ reseptör antagonisti ranitidin ( $100 \mathrm{nmol} ; \mathrm{n}=7$ ) veya histaminerjik $\mathrm{H}_{3} / \mathrm{H}_{4}$ reseptör antagonisti tiyoperamid 
(100 nmol; n=7) enjeksiyonları yapıldı. Enjeksiyonlar 7 gün boyunca her gün sabah saat 09:00-10:00 arasında gerçekleştirildi. 7 gün boyunca, enjeksiyonlardan önce hayvanların tükettikleri yem ve su miktarları hesaplandı ve ardından hayvanların tartımları yapılarak ağırlıkları kaydedildi. 7 . gün deneysel çalışmaların bitiminden sonra hayvanlar derin anestezi altında dekapite edildi.

Çalışmada kullanılan histamin ve reseptör antagonistleri daha önceki çalışmamızda kullandığımız etkin dozlardan seçilmiştir (21).

\section{Serebral Yan Ventriküle İlaç Verilişi}

Serebral yan ventriküle ilaç enjeksiyonları toplam $5 \mu$ içinde yapıldı ve bu miktar sıvı 60 saniye boyunca yavaş infüzyon tarzinda uygulandi.

\section{Yem ve Su Alımının Hesaplanması}

Deneysel çalışmaların başlayacağı ilk gün 100 gram yem ve $50 \mathrm{~mL}$ su hayvanların kafeslerine konarak hayvanların ad libitum beslenmesi sağlandı. İlk enjeksiyon gününün hemen ardından, 2. gün enjeksiyonlar başlamadan önce hayvanların tükettikleri yem ve su miktarları tekrar ölçülerek bir önceki gün ile arasında olan yem, su ağırlığı farklılıkları kaydedildi. Bu yöntemle hayvanların yem ve su alımları 7 gün boyunca takip edildi.

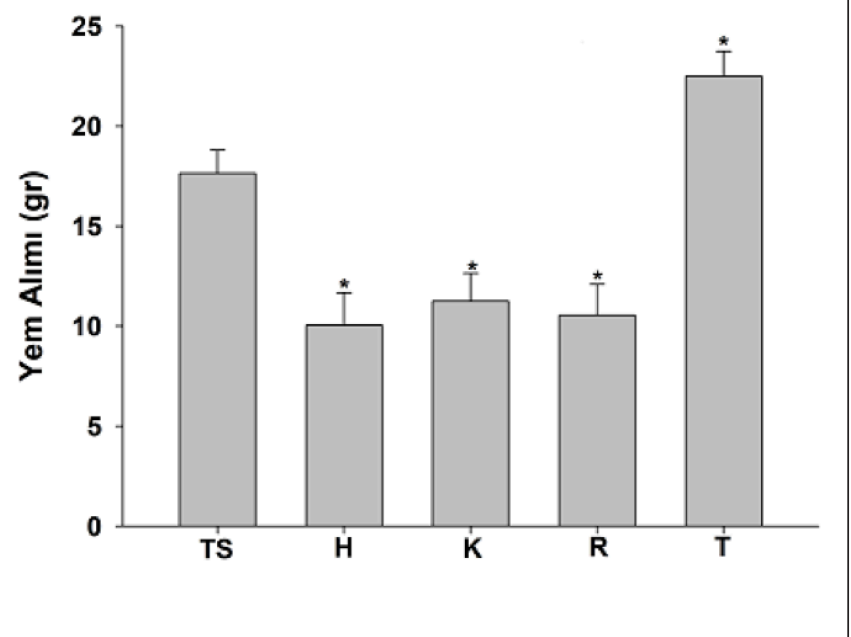

Şekil 1. Histamin ve antagonistlerinin yem alımına etkisi: Sıçanlar, tuzlu su (5 $\mu \mathrm{L}$; s.y.v.; $\mathrm{n}=7)$, histamin (100 nmol; s.y.v.; $\mathrm{n}=7$ ), klorfeniramin (100 nmol; s.y.v.; $\mathrm{n}=7$ ), ranitidin (100 nmol; s.y.v.; $\mathrm{n}=7$ ) veya tiyoperamid (100 nmol; s.y.v.; $\mathrm{n}=7$ ) ile 7 gün boyunca tedavi edildi. Sonuçlar, 7. günde her bir grubun tuzlu suya göre yem alım değişimini göstermektedir. ${ }^{*} \mathrm{p}<0,05$, tuzlu su grubuna göre anlamlı farkı göstermektedir.

s.y.v.: serebral yan ventrikül, TS: tuzlu su, H: histamin, K: klorfeniramin, R: ranitidin, T: tiyoperamid.

\section{Vücut Ağırlıklarının Hesaplanması}

Deneysel çalışmaların başlamasından bir gün önce sıçanların ağırlık ölçümleri yapılarak ilk değerler kaydedildi. Sonrasında takip eden günlerde enjeksiyonlardan önce yapılan yem ve su tartımlarının hemen ardından hayvanların ağırlık tartımları yapılmaya devam edilerek hayvanlardaki ağırlık değişimleri günlük olarak kayıt altına alındı. Bu yöntemle hayvanların ağırlıkları 7 gün boyunca takip edildi.

\section{İstatistiki Değerlendirme}

Çalışmadaki tanımlayıcı istatistikler 7 sıçan için "ortalama \pm standart hata" olarak verildi. Verilerin normal dağılıma uygunluğu Kolmogorov-Smirnov Testi ile değerlendirildi. Grupların karşılaştırmasında tek yönlü ANOVA kullanıldı. Tüm grupların tuzlu su grubuna göre fark gösterip göstermediği Dunnet testi ile değerlendirildi. $\mathrm{p}<0,05$ istatistiksel olarak anlamlı sayıldı. Veriler IBM SPSS Statistics (v23) paket programı ile analiz edildi.

\section{BULGULAR}

Histamin ve Antagonistlerinin Vücut Ağırlığı, Yem ve Su Alımına Etkisi

Çalışmada, 7. günde gruplar arasında yem alımı bakımından fark olup olmadığ 1 araştırıldı ve her bir grubun tuzlu suya göre karşılaştırması yapıldı. 7 gün boyunca, merkezi yolla uygulanan histamin, klorfeniramin $\left(\mathrm{H}_{1}\right.$ reseptör antagonisti) ve ranitidin $\left(\mathrm{H}_{2}\right.$ reseptör antagonisti) tedavilerinin sıçanların ortalama yem alım miktarlarında tuzlu su grubuna göre düşüşe neden olduğu, merkezi tiyoperamid $\left(\mathrm{H}_{3 / 4}\right.$ reseptör antagonisti) tedavisinin ise yem alım miktarlarında artışa yol açtığı ortaya çıkmıştır $(\mathrm{p}<0,05)$ (Şekil 1$)$.

Yem tüketimine benzer şekilde, su alımının değerlendirilmesinde de 7 . günde gruplar arasında su alımı bakımından

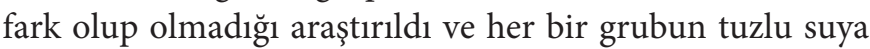
göre karşılaştırması yapıldı. Histamin, klorfeniramin ve ranitidin ile yapılan merkezi tedavilerin sıçanların tuzlu su grubuna göre ortalama su alım miktarlarını azalttığı, tiyoperamid tedavisinin ise sıçanlarda su alım miktarlarında artışa neden olduğu görülmüştür $(\mathrm{p}<0,05)$ (Şekil 2).

Tuzlu su, histamin, klorfeniramin, ranitidin ve tiyoperamid uygulanan grupların başlangıç ağılık ortalamaları sirasiyla $360 \pm 1,0653,368 \pm 1,5237,364 \pm 1,0889,367 \pm 1,0542$, $363 \pm 1,3272$ gramdi. Yapılan karşılaştırmalarda; gruplar arasında 0. gün ağırlıklarında anlamlı bir farklılık olmadığı görülmüştür $(p>0,05)$. 7. günde yapılan ağırlık ölçümleri histamin, klorfeniramin ve ranitidin tedavilerinin uygulandığı gruplarda tuzlu su grubu ile karşılaştırıldığında vücut ağırlıklarının azaldığı görülmüştür. Tiyoperamid tedavisi uygulanan grupta ise vücut ağırlığında artma olduğu ortaya çımıştır $(\mathrm{p}<0,05)($ Şekil 3). 


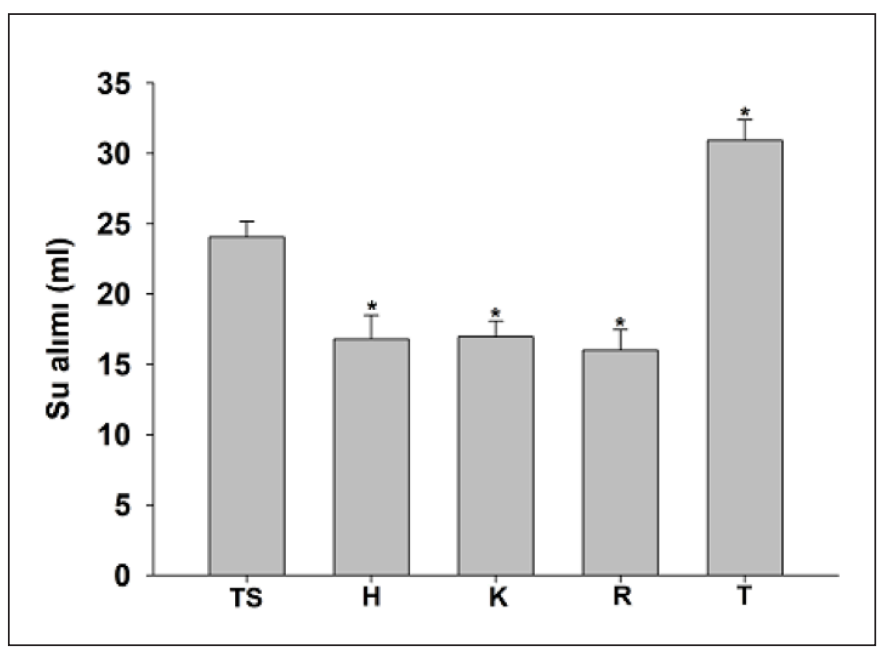

Şekil 2. Histamin ve antagonistlerinin su alımına etkisi: Sıçanlar kronik olarak tuzlu su (5 $\mu \mathrm{L}$; s.y.v.; $\mathrm{n}=7)$, histamin (100 nmol; s.y.v.; $\mathrm{n}=7$ ), klorfeniramin (100 nmol; s.y.v.; $\mathrm{n}=7)$, ranitidin (100 nmol; s.y.v.; $n=7$ ) veya tiyoperamid (100 nmol; s.y.v.; $n=7$ ) ile 7 gün boyunca tedavi edildi. Sonuçlar, 7 . günde her bir grubun tuzlu suya göre su alım değişimini göstermektedir. ${ }^{*} \mathrm{p}<0,05$, tuzlu su grubuna göre anlamlı farkı göstermektedir.

s.y.v.: serebral yan ventrikül, TS: tuzlu su, H: histamin, K: klorfeniramin, R: ranitidin, T: tiyoperamid.

\section{TARTIŞMA}

Çalışmanın sonuçları, 7 gün boyunca merkezi olarak uygulanan histamin ve reseptör antagonistlerinin hayvanların vücut ağırlığına, yem ve su alımı oranlarına etki ettiğini ortaya koymaktadır. Histamin, klorfeniramin, ranitidin tedavisi uygulanan grupların 7. günde tuzlu su gruplarına kıyasla hayvanların vücut ağırlığı, yem ve su alımı üzerinde negatif etkilere neden olduğu bunun tersi olarak tiyopermid tedavisinin ise ölçülen değerlerde artışlara yol açtığı gözlenmiștir.

Histaminerjik hücre gövdeleri karakteristik olarak posterior hipotalamik alanlarda sınırlı bir lokalizasyona sahiptir. Histamin nöronları bu bölgeden beynin geniş bir alanına yaygın projeksiyonlar göndermektedir. Nöronal histamin prekürsörü L-histidin ve histamin $\mathrm{H}_{1}$ reseptörleri, beslenmeyle ilgili çekirdekler dahil olmak üzere hipotalamusta yoğun olarak bulunmaktadır $(22,23)$. Histaminin ve L-histidinin s.y.v. enjeksiyonlarının doza bağlı olarak gida alımını baskıladığı çalışmalarda gösterilmektedir $(5,24)$. Histaminin metabolik yolunu inhibe eden metoprin ile yapılan çalışmalarda endojen histamin miktarlarında oluşan artışlara bağlı olarak yine gida alımının azaldığı ortaya konulmaktadır (5). Histaminin, hipotalamusun suprakiazmatik çekirdeğine yapılan sürekli enjeksiyonlarının da gıda alımını azalttığı gösterilmiştir. Çalışmamızda da bolus şeklinde 7 gün boyunca uygulanan histaminin tuzlu su grubu

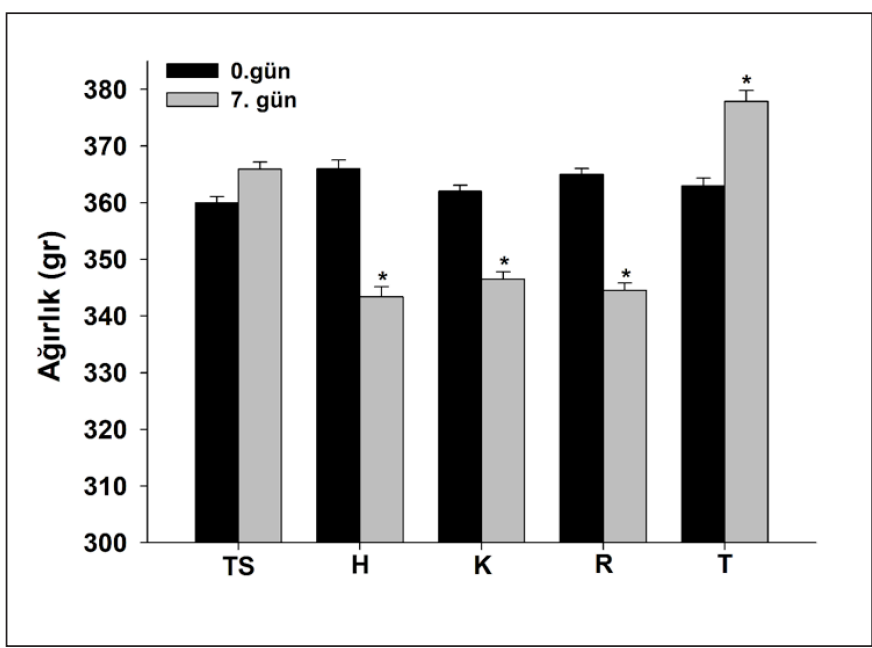

Şekil 3. Histamin ve antagonistlerinin vücut ağırlığına etkisi: Sıçanlar kronik olarak tuzlu su (5 $\mu$ L; s.y.v.; $n=7)$, histamin (100 nmol; s.y.v.; $n=7$ ), klorfeniramin (100 nmol; s.y.v.; $n=7)$, ranitidin (100 nmol; s.y.v.; $n=7)$ veya tiyoperamid (100 nmol; s.y.v.; $n=7)$ ile 7 gün boyunca tedavi edildi. 0. gün, enjeksiyonlar öncesi sıçanların ağırlık değerlerini göstermektedir. 7. gün verileri ise her bir grubun tuzlu su grubuna göre vücut ağırlık değişimini göstermektedir.

s.y.v.: serebral yan ventrikül, TS: tuzlu su, H: histamin, K: klorfeniramin, R: ranitidin, T: tiyoperamid.

ile karşılaştırıldığında gıda alımını azaltması yapılan çalışmalarla paralellik göstermekte ve bu durumun beyin histamin seviyelerinin artışının bir sonucu olarak ortaya çıkmış olabileceğini düşündürmektedir.

Yapılan araştırmalarda, histaminin $\mathrm{H}_{1}$ reseptörlerinin blokajının metoprinin beslenme üzerindeki etkisini hafiflettiğgi gösterilmiştir (25). $\mathrm{H}_{1}$ reseptör agonisti 2-(3-trifluoromethylphenyl) histaminin (FMPH) merkezi enjeksiyonun histamine benzer şekilde gıda alımını inhibe ettiği görülmüştür (5). Yine aynı çalışmada histaminin ve FMPH'nın inhibe edici etkilerinin $\mathrm{H}_{1}$ reseptör antagonisti ile zayıflatıldığ rapor edilmiştir (5). Ayrıca, $\mathrm{H}_{1}$ reseptör antagonisti klorfeniraminin s.y.v. veya doğrudan ventromedial hipotalamus veya paraventriküler nükleusa infüzyonunun, geçici bir beslenmeye yol açtığı da bildirilmektedir $(26,27)$. Histamin $\mathrm{H}_{3}$ reseptörü, histaminerjik sinir terminalleri seviyesinde hem histamin sentezinin hem de salımının oto-inhibisyonuna aracılık etmektedir (28). Çalışmalarda tiyoperamidin, spesifik ve güçlü bir $\mathrm{H}_{3}$ reseptör antagonisti olduğu ve normal geribildirim inhibitör kontrol sistemini ortadan kaldırarak histaminerjik nöron aktivitesini artırdığı görülmektedir (29). Bunu destekleyen çalışmalarda, tiyoperamidin s.y.v. enjeksiyonunun gıda alımını düşürdüğü (30) ve tioperamidin intraperitoneal enjeksiyonunun methoprinin gida tüketiminde oluşturduğu azalmayı desteklediği bildirilmektedir (25). Akut çalışmalarla uyumlu olarak olarak, sıçanlara s.y.v. yolla kronik uygulanan klorfeniramin infüzyonunun, 
aydınlık dönemde gıda alımını artırdığı ve karanlık dönemde ise gıda alımını azalttığı belirtilmektedir (31). Aynı çalışmada, kronik olarak merkezi histamin sentezleyen enzim histidin dekarboksilazın spesifik bir inhibitörü olan $\alpha$-fluoromethylhistidin (FMH) enjeksiyonununda klorfeniramin ile aynı etkilere yol açtığı gösterilmiştir (30). Bahsedilen çalışmada (31), klorfeniraminin ve FMH'nın düşük dozlarda devamlı infüzyonunun etkileri ortaya konulmaktadır. Çalışmamızda ise klorfeniramin daha yüksek dozda bolus şeklinde s.y.v.'ye 7 gün boyunca süresince enjekte edilmiş ve tuzlu su grubu ile karşılaştırıldığında gıda alımında azalmanın olduğu görülmüştür. Yine bahsedilen çalışmada, $\mathrm{H}_{3}$ reseptör antagonisti tiyoperamidin düşük dozlu sürekli infüzyonun gıda alımını yalnızca karanlık periyotta azalttığ 1 görülmüştür (31). Bolus şeklinde $100 \mathrm{nmol}$ tiyoperamidin s.y.v. olarak karanlık dönemden hemen önce infüzyonunun, sıçanlarda gıda alımını güçlü bir şekilde azalttığı ortaya konulmuştur (32). Çalışmamızda ise tiyoperamid aydınlık dönemde yine $100 \mathrm{nmol}$ dozunda bolus şeklinde s.y.v. olarak 7 gün süresince uygulanmış ve tuzlu su grubu ile kıyaslandığında gıda alımını artırdığı görülmüştür. $\mathrm{H}_{2}$ reseptör antagonisti famotidinin ise merkezi kronik uygulanmasinın gıda alımı üzerinde bir etki oluşturmadığ (31). Bunun tersi olarak uzun süreli $\mathrm{H}_{2}$ reseptör antagonisti simetidinin uzun süreli tedavisinin insan ve sıçanlarda gida alımını azalttığı rapor edilmektedir $(33,34)$. Çalışmamızda kullandığımız $\mathrm{H}_{2}$ reseptör antagonisti ranitidinin de 7 günlük tedavisinin gıda alımını azalttığı görülmektedir. En son keşfedilen histamin reseptörü olan histamin $\mathrm{H}_{4}$ reseptörü ile gerçekleştirilen bir çalışmada, $\mathrm{H}_{4}$ reseptör yoksunu olan farelerde gıda alımında bir artışın görüldüğü, $\mathrm{H}_{4}$ reseptör agonisti VUF 8430'un s.y.v. yolla uygulamasından sonra ise gıda tüketiminde bir azalma gerçekleştiği belirtilmektedir (35). Sisplatin ile indüklenmiş anoreksiya modeli oluşturulan farelere $\mathrm{H}_{4}$ reseptör antagonistinin kronik olarak subkutan enjeksiyonlarının sisplatin tarafından oluşturulan anoreksijenik etkileri ortadan kaldırdığı gösterilmiștir (36). $\mathrm{Bu}$ bilgiler, tedavilerde kullanılan ilaçların çeşidinin, veriliş yolunun, uygulama şekli ve zamanının ve son olarak da dozlarının gıda alımı üzerinde farklı etkilere yol açabileceğini göstermektedir.

İlk olarak, güçlü histamin $\mathrm{H}_{1}$ reseptör antagonistleri olduğu kanıtlanan bazı antipsikotikler ve antidepresanların iştah uyarımı ve kilo artışı şeklinde güçlü yan etkilere sahip olduğunun görülmesiyle, histaminerjik sistemin vücut ağırlığ1nın düzenlenmesinde de rol oynayabileceği keşfedilmiştir (37). Bu bulgularla uyumlu şekilde, nöronal histamin vücut ağırlığının homeostatik kontrolünde görev almakta ve merkezi $\mathrm{H}_{1}$ reseptörleri histaminin vücut ağırlığı üzerindeki etkilerine aracilık etmektedir (26). Araştırmalar, histaminin vücut ağırlığının düzenlenmesi üzerindeki etkisini, yalnızca iştah üzerinde oluşturduğu inhibitör etkiler ile değil, bunun yanı sıra metabolik olarak lipolitik etkiler üzerinden de gösterdiği rapor edilmektedir (38). Bununla birlikte, $\mathrm{H}_{2}$ reseptör antagonistlerinden simetidin, famotidin ve ranitidinin periferik olarak sıçanlarda uygulanan uzun süreli tedavilerinin vücut ağırlığında azalmalara yol açtığı bildirilmektedir (39). $\mathrm{H}_{3}$ reseptör antagonistlerinin de vücut ağırlığının düzenlenmesinde etkili olduğu $(39,40)$ ve daha önce de bahsedildiği gibi (31) farklı doz ve zaman aralığına göre vücut ağırlığı üzerinde değişik etkilere sebep olduğu gösterilmektedir. Çalışmamızda da bu belirtilen verilere uygun olarak, histamin, $\mathrm{H}_{1}$ reseptör antagonisti klorfeniramin ve $\mathrm{H}_{2}$ reseptör antagonisti ranitidin tedavilerinin 7 . günkü değerleri tuzlu su grubu ile karşılaştırıldığında vücut ağırlığını azalttığını ve yine çalışmalarla uyumlu olarak $\mathrm{H}_{3}$ reseptör antagonisti tiyoperamidin ise kilo alımına yol açtığını gösterdik.

Histaminerjik nöronların ayrıca su alımının kontrolünde de etkili olduğu bilinmektedir $(2,41)$. Histaminin, beynin fark11 alanlarına s.y.v'ye yapılan enjeksiyonlarının sonucu histaminerjik sistemin baskın dipsojenik etkiler gösterdiği rapor edilmektedir (13). Ayrıca, dehidrasyonun hipotalamik histamin sentezini ve salınımını artırdığı da gösterilmiştir (42). Histaminin oluşturduğu su alımı artışlarına histaminin $\mathrm{H}_{1}$ ve $\mathrm{H}_{2}$ reseptörlerinin aracıllk ettiği rapor edilmektedir (43). $\mathrm{Bu}$ çalışmalara paralel olarak, $\mathrm{H}_{1}$ histaminerjik reseptör antagonisti mepiramin ve $\mathrm{H}_{2}$ histaminerjik reseptör antagonisti simetidinin merkezi enjeksiyonlarının anjiyotensinerjik sistemin uyarımına bağlı oluşan su alımını inhibe ettiği ortaya konulmaktadır (44). Merkezi $\mathrm{H}_{3}$ reseptör agonisti (R)-a-methylhistamine ile yapilan akut tedavide, ani bir içme tepkisi ortaya çıktığ 1 ve su tüketimindeki artışın tiyoperamid tarafından antagonize edildiği bildirilmiştir. Bu veriler beyindeki $\mathrm{H}_{3}$ reseptör aktivasyonunun birincil olarak içme davranışını etkilediğini göstermektedir (5). Çalışmamızda, 7 günlük histamin, $\mathrm{H}_{1}$ reseptör antagonisti klorfeniramin ve $\mathrm{H}_{2}$ reseptör antagonisti ranitidin tedavilerinin tuzlu su grubuna göre su alımını azalttığını ve $\mathrm{H}_{3}$ reseptör antagonisti tiyoperamidin ise su alımını artırdığını ortaya koyduk. Histamin, klorfeniramin ve ranitidin su alımında etkili olan $\mathrm{H}_{1}$ ve $\mathrm{H}_{2}$ reseptörlerini ve merkezi birkaç hormonal yolağın etkisini bloke ederek su alımını azaltmış olabilir. Histaminin otoreseptör özelliğine sahip $\mathrm{H}_{3}$ reseptörleri ise kronik tedaviye yanıt olarak yem alımı ve vücut ağırlığındaki değişimlere paralel şekilde sıvı alımını artırmıştır.

Sonuç olarak çalışmada, 7 gün boyunca merkezi uygulanan bolus şeklindeki histamin ve reseptör antagonistlerinin enjeksiyonlarının yem, su alımı ve vücut ağırlığı üzerinde diğer çalışmalara benzer şekilde etkiler oluşturduğunu saptadık. Çalışmada 7 gün boyunca merkezi histamin uygulan- 
ması hayvanlarda yem ve su tüketiminde azalma ve sonuç olarak hayvanların vücut ağırlığında düşüşe neden oldu. Ayrıca bu çalışma ile merkezi $\mathrm{H}_{1}$ ve $\mathrm{H}_{2}$ reseptörlerinin 7 gün süresince bloke edilmesinin gıda ve su alımını düşürerek vücut ağırlığında azalmaya neden olduğunu, tersine merkezi $\mathrm{H}_{3}$ ve $\mathrm{H}_{4}$ reseptörlerinin bloke edilmesinin ise gida ve su alımı tüketimini artırarak vücut ağırlığında artış oluşturduğunu ortaya koyduk.

\section{Yazarların Makaleye Katkı Beyanı}

Tüm yazarlar, çalışmanın fikir ve tasarım, veri toplama ve işleme, analiz ve verilerin yorumlanması, makalenin önemli bölümlerinin yazılmasına katkı sağlamıştır.

\section{Çıkar Çatışması}

Yazarlar bu araştırma ve makale için herhangi bir çıkar çatışması olmadığını beyan ederler.

\section{Finansal Destek}

Çalışma için herhangi bir finansal destek alınmamıştır.

\section{Etik Kurul Onayı}

Çalışmadaki tüm cerrahi ve deneysel uygulamalar, Bursa Uludağ Üniversitesi Etik Kurul Komitesi tarafından 2021-04/01 Karar No ile onayland.

\section{Hakemlik Süreci}

Kör hakemlik süreci sonrası yayınlanmaya uygun bulunmuş ve kabul edilmiştir.

\section{KAYNAKLAR}

1. Connelly WM, Shenton FC, Lethbridge N, Leurs R, Waldvogel HJ, Faull RL, Lees G, Chazot PL. The histamine H4 receptor is functionally expressed on neurons in the mammalian CNS. Br J Pharmacol. 2009;157(1):55-63.

2. Schwartz JM, Arrang JM, Garbarg M, Pollard H, Ruat M. Histaminergic transmission in the mammalian brain, Physiol Rev. 1991;71:1-51.

3. Wada $\mathrm{H}$, Inagaki $\mathrm{N}$, Yamatodani $\mathrm{A}$, Watanabe $\mathrm{T}$. Is the histaminergic neuron system a regulatory center for wholebrain activity? TINS. 1991;14:415-418.

4. Brown RE, Stevens DR, Haas HL. The physiology of brain histamine. Prog Neurobiol. 2001;63:637-672.

5. Lecklin A, Etu-Seppälä P, Stark H, Tuomisto L. Effects of intracerebroventricularly infused histamine and selective $\mathrm{H} 1$, $\mathrm{H} 2$ and $\mathrm{H} 3$ agonists on food and water intake and urine flow in Wistar rats. Brain Res. 1998;793(1-2):279-288.

6. Malmlöf K, Golozoubova V, Peschke B, Wulff BS, Refsgaard $\mathrm{HH}$, Johansen PB, Cremers T, Rimvall K. Increase of neuronal histamine in obese rats is associated with decreases in body weight and plasma triglycerides. Obesity (Silver Spring). 2006;14(12):2154-2162.
7. Machidori H, Sakata T, Yoshimatsu H, Ookuma K, Fujimoto K, Kurokawa M, Yamatodani A, Wada H. Zucker obese rats: defect in brain histamine control on feeding, Brain Res. 1992;590:180-186.

8. Clineschmidt BV, Lotti VJ. Histamine: Intraventricular injection suppresses ingestive behavior of the cat. Arch Int Pharmacodyn Ther. 1973;206:288-298.

9. Tuomisto L, Eriksson L. Antidiuresis induced by infusions of histamine into the brain ventricles of conscious goats. Eur J Pharmacol. 1979;54:191-201.

10. Lecklin A, Tuomisto L, MacDonald E. Metoprine, an inhibitor of histamine $\mathrm{N}$ - methyltransferase but not catechol-Omethyltransferase, suppresses feeding in sated and food deprived rats. Methods Find Clin Exp Pharmacol. 1995;17:4752.

11. Mercer LP, Kelley DS, Humphries LL, Dunn JD. Manipulation of central nervous system histamine or histaminergic receptors (H1) affects food intake in rats. J Nutr. 1994;7:1029-1036.

12. Haq AU, Bundrant HM, Mercer LP. Food intake is inversely correlated with central nervous system histamine receptor (H1) concentrations in male Sprague-Dawley rats fed normal, low protein, low energy or poor quality protein diets. J Nutr. 1996;126:3083-3089.

13. Leibowitz SF. Histamine: A stimulatory effect on drinking behavior in the rat, Brain Res. 1973;63:440-444.

14. Clapham J, Kilpatrick GJ. Histamine H3 receptor-mediated modulation of water consumption in the rat. Eur J Pharmacol. 1993;232:99-103.

15. Tsuda K, Yoshimatsu H, Niijima A, Chiba S, Okeda T, Sakata T. Hypothalamic histamine neurons activate lipolysis in rat adipose tissue. Exp Biol Med (Maywood ). 2002;227:208-213.

16. Yoshimatsu H, Hidaka S, Niijima A, Sakata T. Histamine neurons down-regulate ob gene expression in rat white adipose tissue. Inflamm Res. 2001;50(suppl 2):72-S73.

17. Masaki T, Chiba S, Yasuda T, Noguchi H, Kakuma T, Watanabe T, Sakata T, Yoshimatsu H. Involvement of hypothalamic histamine $\mathrm{H} 1$ receptor in the regulation of feeding rhythm and obesity. Diabetes. 2004;53:2250-2260.

18. Fülöp AK, Földes A, Buzás E, Hegyi K, Miklós IH, Romics L, Kleiber M, Nagy A, Falus A, Kovács KJ. Hyperleptinemia, visceral adiposity, and decreased glucose tolerance in mice with a targeted disruption of the histidine decarboxylase gene. Endocrinology. 2003;144:4306-4314.

19. Takahashi K, Suwa H, Ishikawa T, Kotani H. Targeted disruption of $\mathrm{H} 3$ receptors results in changes in brain histamine tone leading to an obese phenotype. J Clin Invest. 2002;110:1791-1799.

20. Paxinos G, Watson C. The Rat Brain in Stereotaxic Coordinates (Fourth edition). New York, Academic Press, 2005.

21. Niaz N, Guvenc G, Altinbas B, Berk Toker M, Aydin B, Udum-Kucuksen D, Alcay S, Gokce E, Ustuner B, Yalcin M. Intracerebroventricular injection of histamine induces the hypothalamic-pituitary-gonadal axis activation in male rats. Brain Res. 2018;1699:150-157. 
22. Taylor KM, Snyder SH. Isotopic microassay ofhistamine, histidine, histidine decarboxylase and histamine methyltransferase in brain tissue. J Neurochem. 1972;19:13431358.

23. Palacios JM, Wamsley JK, Kuhar MJ. The distribution of histamine H1-receptor in the rat brain: An autoradiographic study. Neuroscience. 1981;6:15-37.

24. Yoshimatsu H, Chiba S, Tajima D, Akehi Y, Sakata T. Histidine suppresses food intake through its conversion into neuronal histamine. Exp Biol Med (Maywood). 2002;227(1):63-68.

25. Lecklin A, Tuomisto L. The blockade of $\mathrm{H}_{1}$ receptors attenuates the suppression of feeding and diuresis induced by inhibition of histamine catabolism. Pharmacol Biochem Behav. 1998;59(3):753-758.

26. Ookuma K, Yoshimatsu H, Sakata T, Fujimoto K, Fukagawa $\mathrm{K}$. Hypothalamic sites of neuronal histamine action on food intake by rats. Brain Res. 1989;490:268-275.

27. Sakata T, Ookuma K, Fukagawa K, Fujimoto K, Yoshimatsu H, Shiraishi T, Wada H. Blockade of the histamine H1-receptor in the rat ventromedial hypothalamus and feeding elicitation. Brain Res. 1988;441:403-407.

28. Arrang JM, Garbarg M, Schwartz JC. Autoinhibition of brain histamine release mediated by a novel class (\%) of histamine receptor. Nature. 1983;302:832-837.

29. Arrang JM, Garbarg M, Lancelot JC, Lecomte JM, Pollard H, Robba M, Schunack W, Schwartz JC. Highly potent andselective ligands for histamine H3-receptors. Nature. 1987;327:117-123.

30. Ookuma K, Sakata T, Fukagawa K, Yoshimatsu H, Kurokawa M, Machidori H, Fujimoto K. Neuronal histamine in the hypothalamus suppresses food intake in rats. Brain Res. 1993;628:235-242.

31. Doi T, Sakata T, Yoshimatsu H, Machidori H, Kurokawa M, Jayasekara LA, Niki N. Hypothalamic neuronal histamine regulates feeding circadian rhythm in rats. Brain Res. 1994;641:311-318.

32. Sakata T, Fukagawa K, Ookuma K, Fujimoto K, Yoshimatsu $\mathrm{H}$, Yamatodani A, Wada H. Hypothalamic neuronal histamine modulates ad libitum feeding by rats. Brain Res. 1990;537:303306.
33. Støa-Birketvedt G. Effect of cimetidine suspension onappetite and weight in overweight subjects. Br Med J. 1993;306:10911093.

34. Støa-Birketvedt G, Løvhaug N, Vonen B, Florholmen J. $\mathrm{H} 2$-receptor antagonist reduces food intake and weight gain in rats by non-gastric acid secretory mechanisms. Acta Physiol Scand. 1997;161(4):489-494.

35. Haas HL, Sergeeva OA, Selbach O. Histamine in the nervous system. Physiol Rev. 2008;88:1183-1241.

36. Yamamoto K, Rikuya O, Atsushi Y. Effects of a histamine H4 receptor antagonist on cisplatin-induced anorexiain mice. Neurosci Lett. 2018;676:103-107.

37. Kalucy RS. Drug-induced weight gain. Drugs. 1980;19:268278.

38. Bugajski J, Janusz Z. Lipolytic responses induced by intracerebroventricular administration of histamine in the rat. Agents Actions. 1981;11:147-150.

39. Malmlöf K, Zaragoza F, Golozoubova V, Refsgaard HHF, Cremers T, Raun K, Wulff BS, Johansen PB, Westerink B, Rimvall K. Influence of a selective histamine $\mathrm{H} 3$ receptor antagonist on hypothalamic neural activity, food intake and body weight. Int J Obes (Lond). 2005;29:1402-1412.

40. Hancock AA, Bennani YL, Bush EN, Esbenshade TA, Faghih R, Fox GB, Jacobson P, Knourek-Segel V, Krueger KM, Nuss ME, Pan JB, Shapiro R, Witte DG, Yao BB. Antiobesity effects of A-331440, a novel non-imidazole histamine $\mathrm{H} 3$ receptor antagonist. Eur J Pharmacol. 2004;487:183-197.

41. Onodera K, Yamatodani A, Watanabe T, Wada $H$. Neuropharmacology of the histaminergic neuron system in the brain and its relationship with behavioral disorders. Prog Neurobiol. 1994;42:685-702.

42. Kjaer A, Knigge U, Rouleau A, Garbarg M, Warberg J. Dehydration-induced release of vasopressin involves activation of hypothalamic histaminergic neurons. Endocrinology. 1994;135:675-681.

43. Kraly FS. Drinking elicited by eating. In: Epstein AN, Morrison A, ed. Progress in Psychobiology and Physiological Psychology. vol. 14. New York: Academic Press;1990:67-133.

44. Silva MDC, Ramos AC, Athanazio R, Barbetta M, Fregoneze JB. Central $\mathrm{H} 1$ and $\mathrm{H} 2$ receptor participation in the control of water and salt intake in rats. Physiol Behav. 2005;84:233-243. 